\title{
Pengungkapan Enterprise Risk Management dan Nilai Perusahaan: Peran Moderasi Umur dan Ukuran Perusahaan
}

\author{
Ni Kadek Ayu Asri Anggreni1 \\ Fakultas Ekonomi dan Bisnis \\ Universitas Udayana, Indonesia
}

\author{
Dodik Ariyanto ${ }^{3}$ \\ Fakultas Ekonomi dan Bisnis \\ Universitas Udayana, Indonesia
}

\author{
Herkulanus Bambang Suprasto ${ }^{2}$ \\ Fakultas Ekonomi dan Bisnis \\ Universitas Udayana, Indonesia
}

I Gusti Ngurah Agung Suaryana ${ }^{4}$
Fakultas Ekonomi dan Bisnis
Universitas Udayana, Indonesia
Surel : ayuasrianggreni@gmail.com ABSTRAK

Tujuan penelitian untuk memperoleh bukti empiris mengenai pengaruh pengungkapan enterprise risk management (ERM) pada nilai perusahaan dengan peran umur dan ukuran perusahaan sebagai pemoderasi. Teknik penentuan sampel yang digunakan a dalah dengan teknik purposive sampling. Data yang digunakan dalam penelitian ini adalah data sekunder yang diperoleh dari laporan tahunan perusahaan asuransi dan lembaga pembiayaan yang terdaftar di Bursa Efek Indonesia periode 2018-2019. Teknik analisis data menggunakan analisis moderated regression analysis (MRA). Hasil analisis menunjukkan bahwa pengungkapan ERM berpengaruh negatif signifikan pada nilai perusahaan lembaga pembiayaan dan asuransi. Umur perusahaan memperlemah pengaruh pengungkapan ERM pada nilai perusahaan dengan jenis moderasi quasi moderator. Ukuran perusahaan tidak terbukti memoderasi pengaruh pengungkapan ERM pada nilai perusahaan dan termasukjenis prediktor moderasi.

Kata Kunci: Nilai Perusahaan; Enterprise Risk Management; Umur Perusahaan; Ukuran Perusahaan.

\section{Enterprise Risk Management Disclosure and Firm Value: Moderation Role by Age and Size of The Company}

\section{ABSTRACT}

The purpose of the study was to obtain empirical evidence regarding the effect of enterprise risk management (ERM) disclosure on firm value with the role of age and firm size as moderating. The sampling technique used is purposive sampling technique. The data used in this study is secondary dataobtained from the annual reports of insurance companies and financial institutions listed on the Indonesia Stock Exchange for the 2018-2019 period. The data analysis technique used moderated regression analysis (MRA). The results of the analysis show that ERM disclosure has a significant negative effect on the firm value of financing and insurance institutions. Firm age weakens the effect of ERM disclosure on firm value with a quasi moderator type of moderation. Firm size is not proven to moderate the effect of ERM disclosure on firm value and is a moderating predictor.

Keywords: $\quad$ Firm Value; Enterprise RiskManagement Disclosure; Company Age; Company Size.

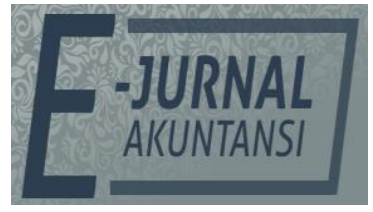

e-ISSN 2302-8556

Vol. 31 No. 11

Denpasar, November 2021

Hal. 2867-2881

10.24843/EJA.2021.v31.i11.p15

PENGUTIPAN:

Anggreni, N. K. A. A., Suprasto, H. B., Ariyanto, D., \& Suaryana, I. G. N. A. (2021). Pengungkapan Enterprise Risk

Management dan Nilai

Perusahaan: Peran Moderasi Umur dan Ukuran

Perusahaan. E-Jurnal Akuntansi, 31(11), 2867-2881

RIWAYAT ARTIKEL:

Artikel Masuk: 6 Juli 2021

Artikel Diterima: 2 Agustus 2021

Artikel dapat diakses: https:/ / ojs.unud.ac.id/index.php/Akuntansi/index 


\section{PENDAHULUAN}

Setiap perusahaan memiliki tujuan untuk meningkatkan keuntungan dan kemakmuran pemilik perusahaan atau para pemegang saham. Peningkatan keuntungan dan kemakmuran perusahaan dapat tercapai melalui peningkatan nilai perusahaan (Utomo \& Christy, 2017). Perusahaan perlu meningkatkan nilai perusahaanya agar dapat menjadi perusahaan yang memiliki reputasi baik. Ketika suatu perusahaan telah memiliki reputasi yang baik, maka akan memperoleh kepercayaan publik, serta dapat menarik para investor untuk melakukan investasi di perusahaan tersebut. Investasi ini akan menyediakan modal bagi perusahaan untuk dapat menunjang proses pengembangan usaha guna meningkatkan nilai perusahaan (Brio et al., 2003), (Dushnitsky \& Lenox, 2006), dan (Ehie \& Olibe, 2010).

Nilai perusahaan adalah nilai yang mencerminkan harga yang bersedia dibayarkan oleh para investor untuk suatu perusahaan (Prabowo et al, 2018). Menurut Harmono (2009), nilai perusahaan adalah kinerja perusahaan yang dicerminkan oleh harga saham yang dibentuk oleh permintaan dan penawaran pasar modal yang merefleksikan penilaian masyarakat terhadap kinerja perusahaan. Kinerja perusahaan dapat dinilai dari laporan tahunan perusahaan. Laporan tahunan merupakan laporan perkembangan dan pencapaian yang berhasil di raih organisasi dalam setahun, mencakup laporan keuangan dan prestasi akan kinerja perusahaan selama setahun (Prayudi, 2007:135). Melalui laporan tahunan, pihak yang berkepentingan dapat menganalisis perusahaan baik dari segi informasi finansial dan non-finansial perusahaan untuk membuat keputusan.

Nilai perusahaan perlu dipertahankan karena dapat memengaruhi persepsi para investor terhadap tingkat keberhasilan perusahaan yang sering dikaitkan dengan harga saham (Khanna \& Sonti, 2004). Investor mengharapkan harga saham terus meningkat atau minimal harga yang sama. Peningkatan harga saham yang stabil mampu memberikan kemakmuran maksimum bagi para pemegang saham (Ross et al., 2013). Nilai perusahaan memiliki hubungan yang cukup erat dengan pasar modal (Suryani, 2017), sehingga nilai perusahaan ini akan sangat berpengaruh pada harga saham yang di perdagangkan. Ketika harga saham meningkat maka nilai perusahaan juga akan mengalami peningkatan, begitu pula sebaliknya.

Saat ini, di Indonesia Lembaga Jasa Keuangan Non-Bank (LJKNB) sedang menjadi perhatian Otoritas Jasa keuangan (OJK) dalam penerapan manajemen risiko bagi LJKNB melalui revisi POJK No. 1/POJK.05/2015 yaitu POJK No 44/POJK.05/2020. Seiring meningkatnya kegiatan usaha LJKNB dengan risiko yang semakin kompleks perlu diimbangi dengan penerapan manajemen risiko yang memadai, efektif, dan terukur. Implementasi peraturan ini ditujukan untuk meningkatkan kinerja LJKNB.

Signalling theory yang diperkenalkan oleh Akerlof (1970) menyatakan bahwa informasi mempunyai nilai, dan di dalam suatu transaksi para pihak yang terlibat memiliki tingkat informasi yang berbeda. Isu utama artikel Akerlof (1970) berkaitan dengan kualitas dan ketidakpastian. Ilustrasi yang digunakan untuk menggambarkan realitas adalah dengan menggunakan pasar mobil. Klasifikasi mobil disederhanakan dalam dua kutup kualitas yaitu kualitas baik dan kualitas 
buruk yang diberi istilah 'lemons'. Jika penjual mobil bagus tidak memberi sinyal mengenai kualitas mobilnya, maka akan berlaku hukum Gresham, "the bad cars tend to drives out the good cars". Bagi Akerlof, penelitiannya menunjukkan terjadi informasi asimetri antara penjual dan pembeli, dimana penjual memiliki informasi lebih dibanding pembeli. Untuk menghindarkan adverse selection, penjual barang berkualitas memberikan signal mengenai informasi kualitas barang yang dijual sehingga dapat diakses para pembeli (Rura, 2010). Pengungkapan ERM yang dilakukan perusahaan, tentu akan memberikan sinyal bahwa perusahaan memiliki tata kelola yang baik dan mampu mengelola risiko perusahaan, sehingga stakeholder akan memberikan nilai lebih atas informasi ini.

Pada Februari 2018, ISO (International Organization for Standarization) menerbitkan International Standar ISO 31000:2018 Risk Management-Guidelines sebagai revisi terhadap standar terdahulu, ISO 31000:2009 Risk ManagementPrinciples and Guidelines (Susilo \& Riwu, 2018). ISO 31000 merupakan sebuah standar internasional yang dikeluarkan oleh ISO untuk mengelola risiko. Standar internasional ini dapat digunakan untuk berbagai kegiatan individu, kelompok maupun organisasi. Penggunaan standar ini bersifat umum, artinya dapat digunakan untuk berbagai sektor ind ustri (Susilo \& Riwu, 2018). ISO31000 terbagi menjadi tiga bagian yaitu prinsip-prinsip manajemen risiko, kerangka kerja manajemen risiko dan proses manajemen risiko.

ISO 31000:2018 dapat digunakan untuk seluruh jenis entitas/organisasi dengan semua jenis risiko yang dihadapi. ISO 31000:2018 dibangun dari kepedulian stakeholders terhadap pengelolaan risiko dan tidak hanya pada penilai risiko yang profesional. ISO 31000:2018 membantu perusahaan dalam mengelola efektifitas strategi manajemen risiko untuk mengidentifikasi dan memitigasi risiko. ISO 31000:2018 memiliki tujuan untuk melibatkan budaya individu dan entitas agar peka terhadap pentingnya memantau risiko. ISO 31000:2018 memiliki keunggulan esensial dalam memberikan panduan yang lebih mendetail dan komprehensif. Keberadaan prinsip manajemen risiko, penetapan konteks eksternal, dan pemisahan antara kerangka kerja dengan proses manajemen risiko menjadi keunggulan kompetitif yang dimiliki oleh ISO 31000. Fakta bahwa standar ISO 31000 telah diakui dan diadaptasi sebagai standar manajemen risiko di hingga 70 negara juga menunjukkan bahwa ISO 31000 telah bertahan dari uji kelayakan oleh berbagai negara (Susilo \& Riwu, 2018).

Penelitian sebelumnya yang dilakukan Bertinetti et al. (2013), Devi et al. 2017, Hoyt \& Liebenberg (2011), Iswajuni et al. (2018), Sari (2020) mengaitkan hubungan antara ERM dengan nilai perusahaan dan menemukan bahwa penerapan ERM berdampak positif terhadap nilai perusahaan. Hasil empiris mendukung bahwa perusahaan yang menerapkan ERM mampu meningkatkan nilai perusahaan sebesar 17\% (Hoyt \& Liebenberg, 2011) lebih tinggi dari perusahaan yang tidak menerapkan ERM (Iswajuni et al., 2018). Hasil penelitian tersebut tidak sejalan dengan penelitian yang dilakukan oleh (Aditya \& Naomi, 2017), (Ardianto \& Rivandi, 2018), (Mariani \& Suryani, 2018), (Pamungkas \& Maryati, 2017) menyatakan bahwa ERM tidak berpengaruh terhadap nilai perusahaan.

Perbedaan hasil penelitian yang dilakukan oleh peneliti terdahulu memotivasi penulis untuk menguji kembali pengungkapan ERM terhadap 
penentu nilai perusahaan dengan memasukkan variabel yang di duga memoderasi atau memperkuat hubungan pengungkapan ERM pada nilai perusahaan, yaitu variabel umur dan ukuran perusahaan. D'Amato \& Falivena (2020) menemukan bahwa umur dan ukuran perusahaan memperkuat pengaruh positif pengungkapan corporate social responsibillity (CSR) pada nilai perusahaan. Kemudian Narayana \& Wirakusuma (2021) menemukan bahwa ukuran perusahaan memperkuat pengaruh positif pengungkapan CSR pada nilai perusahaan.

Umur dan ukuran memperkuat pengaruh positif pengungkapan CSR pada nilai perusahaan, ini menujukkan semakin tinggi pengungkapan CSR yang dilakukan perusahaan, maka semakin tinggi pula nilai perusahaan, terutama pada perusahaan yang memiliki umur dewasa dan ukuran perusahaan besar (D'Amato \& Falivena, 2020). Begitu pula dengan pengungkapan informasi lain yang dilakukan perusahaan, seperti pengungkapan Enterprise Risk Management (Hoyt \& Liebenberg, 2011). Ini menunjukkan semakin lama perusahaan tersebut berdiri, semakin terlihat kematangan perusahaan dalam mengatasi risiko yang dihadapi, yang kemudian diungkapkan dalam pengungkapan ekstensif dan terinci mengenai manajemen risiko perusahaan pada laporan tahunan perusahaan. Selain itu, dengan melakukan ini dapat meningkatkan transparansi perusahaan yang dapat meningkatkan kepercayaan investor terhadap perusahaan yang telah melakukan tata kelola perusahaan dengan baik. Ini sejalan dengan terori sinyal yang menjelaskan bahwa tingkat kematangan perusahaan ditunjukkan oleh bagaimana perusahaan merespon masing-masing risiko yang dihadapinya, semakin baik perusahaan dalam mengelola risiko yang dihadapinya, sinyal yang diberikan kepada investor juga akan lebih baik dalam hal ini adalah sinyal positif dan sebaliknya (Rujiin \& Sukirman, 2020).

Kemudian ukuran perusahaan yang berskala besar memungkinkan banyak masalah itu muncul di perusahaan, ini akan berdampak pada luasnya pengungkapan yang diterapkan oleh manajemen (D'Amato \& Falivena, 2020). Ini sejalan dengan teori keagenan yang menjelaskan bahwa perusahaan yang berukuran besar diawasi oleh investor perusahaan karena jumlah risiko yang dihadapi juga lebih besar. Untuk menjaga reputasi dan nama baik perusahaan, manajer akan melakukan transparansi dalam pengelolaannya risiko perusahaan dengan baik untuk meningkatkan transparansi dan menjaga kepercayaan investor institusi (Rujiin \& Sukirman, 2020). Jadi ketika perusahaan telah matang dan berskala besar, maka perusahaan akan menemukan semakin banyak risiko dan semakin baik dalam mengelola risiko yang akan dihadapi dengan mengungkapan kepada para stakeholder dalam laporan tahunan perusahaan karena stakeholder akan sangat menyukai informasi penting ini dan akan memberikan nilai yang lebih terhadap perusahaan tersebut.

Penelitian ini memberikan hal berbeda dari penelitian sebelumnya. Menambahkan variabel moderasi umur dan ukuran perusahaan secara bersamaan, dimana penelitian sebelumnya meneliti hubungan langsung umur dan ukuran perusahaan pada nilai perusahaan. Kemudian indikator pengungkapan Enterprise Risk Management menggabungkan standar ISO 31000: 2018 yang diterapkan pada Badan Standardisasi Nasional 2018-2023 serta POJK No 44/POJK.05/ 2020. 


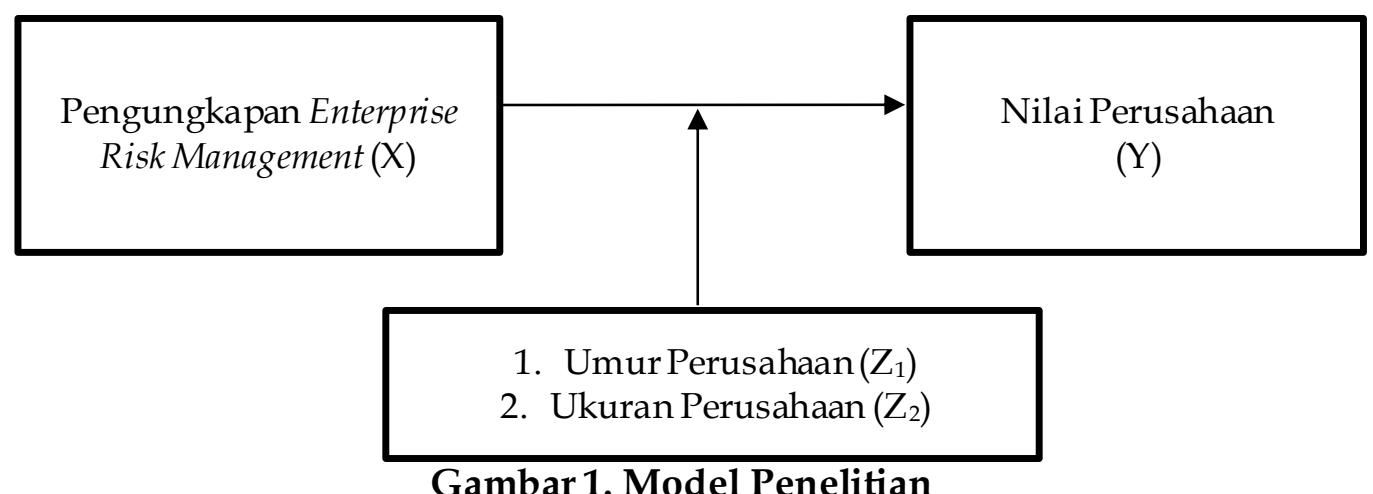

Sumber: Data Penelitian, 2020

Penelitian Jensen \& Meckling (1976) menyatakan bahwa signalling theory adalah suatu tindakan yang diambil oleh manajemen perusahaan yang memberikan petunjuk bagi investor tentang bagaimana manajemen memandang prospek perusahaan. Pengungkapan Enterprise Risk Management (ERM) adalah upaya perusahaan memberikan sinyal kepada stakeholder untuk memberikan informasi privat yang sangat diminati stakeholder guna menghindari asimetri informasi antara perusahaan dengan stakeholder. Stakeholder memiliki hak untuk memperoleh informasi mengenai aktivitas-aktivitas yang dilakukan oleh perusahaan dalam meminimalkan kerugian yang mungkin muncul bagi stakeholder. Salah satu informasi yang sangat diperlukan oleh stakeholder adalah informasi tentang profil risiko perusahaan dan pengelolaan atas risiko (ERM) tersebut. Implementasi ERM dalam suatu perusahaan dapat membantu mengontrol aktivitas manajemen sehingga perusahaan dapat meminimalisasi terjadinya kecurangan (fraud) yang dapat merugikan perusahaan dan stakeholder. Berdasarkan hasil penelitian Bertinetti et al. (2013), Devi et al. (2017), Hoyt \& Liebenberg (2011), dan Iswajuni et al. (2018) meneliti hubungan antara ERM dengan nilai perusahaan dan menemukan bahwa penerapan ERM berdampak positif terhadap nilai perusahaan. Hasil empiris mendukung bahwa perusahaan yang menerapkan Enterprise Risk Management akan meningkatkan nilai perusahaan sebesar 17\% (Hoyt \& Liebenberg, 2011) lebih tinggi dari perusahaan yang tidak menerapkan ERM (Iswajuni et al., 2018). Jadi pengungkapan ERM yang berkualitas tinggi pada suatu perusahaan akan memberikan dampak positif terhadap persepsi pelaku pasar (Baxter et al., 2013). Persepsi positif yang dimiliki oleh pelaku pasar atas informasi perusahaan akan mendorong para pelaku pasar untuk memberikan harga yang tinggi pada perusahaan tersebut sehingga nilai perusahaan akan menjadi tinggi. Berdasarkan uraian tersebut maka dirumuskan hipotesis sebagai berikut:

$\mathrm{H}_{1}$ : pengungkapan enterprise risk management berpengaruh positif pada nilai perusahaan.

Hipotesis ini dilandaskan atas signalling theory. Pada signalling theory menunjukan bahwa semakin lama perusahaan tersebut berdiri maka semakin luas pengungkapannya Enterprise Risk Management (ERM) yang dilakukan oleh pimpinan perusahaan (Rujiin \& Sukirman, 2020). Ini didasarkan atas semakin tumbuhnya kematangan suatu perusahaan pasti akan memiliki pengalaman yang banyak dalam menghadapi risiko perusahaan hingga saat ini. Dengan pengalaman menghadapi risiko tersebut maka pimpinan perusahaan sudah 
memiliki strategi yang tepat yang diterapkan di perusahaan sehingga dapat menjaga stabilitas perusahaan dan meningkatkan keuntungan perusahaan. Kondisi perusahaan yang stabil akan membuat pemimpin perusahaan mengungkapkan ERM dengan transparan untuk memberikan sinyal positif untuk menarik investor berinvestasi di perusahaan yang mereka jalankan. Umur perusahaan adalah berapa lama perusahaan tersebut berdiri dalam menjalankan bisnisnya. Umur perusahaan menjadi perhatian investor dalam berinvestasi dikarenakan umur perusahaan menunjukkan bahwa perusahaan tersebut terus bertahan dan merupakan bukti bahwa perusahaan tersebut mampu bersaing dan dapat memilih peluang yang ada dalam ekonomi (Bogodistov \& Wohlgemuth, 2017). Berdasarkan hasil penelitian D'Amato \& Falivena (2020) menemukan bahwa umur perusahaan berpengaruh positif pada pengungkapan corporate social responsibillity (CSR) pada nilai perusahaan. Pengungkapan informasi lain oleh perusahaan seperti pengungkapan Enterprise Risk Management juga cenderung mampu meningkatkan nilai perusahaan ketika perusahaan dalam kondisi umur dewasa. Berdasarkan uraian tersebut maka dirumuskan hipotesis sebagai berikut: $\mathrm{H}_{2}$ : umur perusahaan memperkuat pengaruh pengungkapan enterprise risk management pada nilai perusahaan.

Jensen \& Meckling (1976) menyatakan bahwa hubungan keagenan merupakan sebuah persetujuan (kontrak) di antara dua pihak, yaitu prinsipal dan agen. Prinsipal memberi wewenang kepada agen untuk mengambil keputusan atas nama prinsipal. Teori ini menjelaskan bahwa semakin besar ukuran suatu perusahaan maka transparansi pengelolaan risiko semakin luas, ini dikarenakan ukuran perusahaan yang besar memungkinkan banyak risiko yang dihadapi perusahaan (Rujiin \& Sukirman, 2020). Ukuran perusahaan menjelaskan kecil atau besar sebuah perusahaan dinilai atas aset yang dimiliki perusahaan tersebut. Ukuran perusahaan yang besar berarti semakin banyak investor menanamkan modal di perusahaan tersebut. Hal ini menyebabkan perusahaan memiliki kewajiban mengungkapkan Enterprise Risk Management (ERM) kepada pihak prinsipal (pemegang saham) sebagai bentuk tanggungjawab kepada investor bahwa perusahaan mampu sebagai wakil dalam mengelola modal dan risiko yang dihadapi perusahaan. Berdasarkan D'Amato \& Falivena (2019) menemukan bahwa ukuran perusahaan memperkuat pengaruh positif pengungkapan corporate social responsibillity (CSR) pada nilai perusahaan. Narayana \& Wirakusuma (2021) juga menemukan ukuran perusahaan memperkuat pengaruh positif pengungkapan CSR pada nilai perusahaan. Pengungkapan informasi lain oleh perusahaan seperti pengungkapan enterprise risk management juga cenderung mampu meningkatkan nilai perusahaan ketika perusahaan dalam ukuran perusahaan besar. Jadi dengan adanya ukuran perusahaan yang semakin besar, akan meningkatkan pengungkapan ERM sehingga nilai perusahaan meningkat. Berdasarkan uraian tersebut maka dirumuskan hipotesis sebagai berikut:

$\mathrm{H}_{3}$ : ukuran perusahaan memperkuat pengaruh pengungkapan enterprise risk management pada nilai perusahaan. 


\section{METODE PENELITIAN}

Penelitian ini dilakukan pada Bursa Efek Indonesia (BEI) melalui website IDX yaitu www.idx.co.id dengan mengunduh laporan keuangan tahunan perusahaan subsektor lembaga pembiayaan dan asuransi tahun 2018-2019. Penentuan sektor ini didasarkan atas kedua subsektor tersebut merupakan Lembaga Jasa Keuangan Non-Bank (LJKNB) yang saat ini di Indonesia menjadi perhatian Otoritas Jasa keuangan (OJK) dalam penerapan manajemen risiko bagi LJKNB melalui revisi POJK No. 1/ POJK.05/ 2015 yaitu POJK No 44/ POJK.05/2020. Pengelolaan risiko di sektor jasa keuangan membutuhkan dukungan menyeluruh dari semua stakeholders termasuk pembuatan kerangka manajemen risiko yang sesuai dengan kompleksitas dan produk LJKNB. Seiring meningkatnya kegiatan usaha LJKNB dengan risiko yang semakin komplek perlu diimbangi dengan penerapan manajemen risiko yang memadai, efektif, dan terukur.

Populasi pada penelitian ini adalah perusahaan lembaga pembiayaan dan asuransis di Bursa Efek Indonesia tahun 2018-2019. Total perusahaan yang tercatat tahun 2019 adalah 32 perusahaan. Kriteria yang digunakan dalam pemilihan sampel adalah perusahaan subsektor lembaga pembiayaan dan asuransi yang terdaftar di Bursa Efek Indonesia tahun 2018-2019 secara berturut-turut dan perusahaan subsektor lembaga pembiayaan dan asuransi yang terdaftar di Bursa Efek Indonesia tahun 2018-2019 yang mempublikasikan laporan tahunan lengkap pada periode 2018-2019.

Tabel 1. Sampel Perusahaan Sub Sektor Lembaga Pembiayaan dan Asuransi Tahun 2018-2019

\begin{tabular}{lc}
\hline \multicolumn{1}{c}{ Kriteria } & $\begin{array}{c}\text { Jumlah } \\
\text { Perusahaan }\end{array}$ \\
\hline $\begin{array}{l}\text { Perusahaan subsektor lembaga pembiayaan dan asuransi yang } \\
\text { terdaftar di Bursa Efek Indonesia tahun 2019 }\end{array}$ & 32 \\
$\begin{array}{l}\text { Perusahaan subsektor lembaga pembiayaan dan asuransi yang } \\
\text { terdaftar di Bursa Efek Indonesia tahun 2018-2019 secara berturut- }\end{array}$ & 30 \\
turut. & \\
Data Outlier & $(7)$ \\
Jumlah Sampel yang Memenuhi Kriteria & 23 \\
Jumlah Sampel dalam2 Tahun Pengamatan & 46 \\
\hline
\end{tabular}

Sumber: Data Penelitian, 2020

Berdasarkan uji casewise diagnostics terdapat 7 data outlier pada penelitian ini. Hal ini terjadi karena terdapat ketimpangan data dari 7 nilai perusahaan tersebut, sehingga untuk memenuhi uji asumsi klasik maka pada penelitian ini data outlier tidak digunakan. Kemudian data yang digunakan dalam penelitian ini adalah menggabungkan data cross section dan time serries, namun tujuan penelitian tidak menginginkan adanya analisis terhadap pengaruh perbedaan entitas (individu) dan atau pengaruh perbedaan periode pengamatan. Pengumpulan data dilakukan dengan cara dokumentasi. Teknis analisis data yang digunakan dalam penelitian ini adalah pertama uji asumsi klasik yang meliputi uji normalitas, uji autokorelasi dan uji heteroskedastisitas. Selanjutnya dilakukan uii regresi moderated regression analysis (MRA) menggunakan programSPSS (Statistical Product and Service Solution) serta dilanjutkan uji kelayakan model dengan analisis koefisien determinasi, uji kesesuaian model (uji f), dan uji statistik t. Persamaan MRA pada penelitian ini adalah sebagai berikut. 


$$
Y=\alpha+\beta_{1} X+\beta_{2} Z_{1}+\beta_{3} Z_{2}+\beta_{4} X^{\star} Z_{1}+\beta_{5} X^{\star} Z_{2}+\varepsilon
$$

Dengan:

\begin{tabular}{|c|c|}
\hline Y & \\
\hline$x$ & \\
\hline & $=$ Pengungkapan Enterprise Risk Managemer \\
\hline $\mathrm{Z}_{1}$ & $=$ Umur Perusahaan \\
\hline $\mathrm{Z}_{2}$ & $=$ Ukuran Perusahaan \\
\hline a & $=$ Konstanta \\
\hline$\beta_{12345}$ & $=$ Koefisien Regresi \\
\hline & $=$ standar error \\
\hline
\end{tabular}

\section{HASIL DAN PEMBAHASAN}

Statistik deskriptif memberikan informasi mengenai karakteristik variabel penelitian yang terdiri atas jumlah pengamatan, nilai minimum, nilai maksimum, nilai rata-rata, dan deviasi standar. Tabel 2, memperlihatkan hasil statistik deskriptif.

Tabel 2. Hasil Uji Statistik Deskriptif

\begin{tabular}{|c|c|c|c|c|c|}
\hline Variabel & $\begin{array}{l}\text { Jumlah } \\
\text { Sampel }\end{array}$ & $\begin{array}{c}\text { Nilai } \\
\text { Minimum }\end{array}$ & $\begin{array}{c}\text { Nilai } \\
\text { Maksimum }\end{array}$ & $\begin{array}{c}\text { Nilai } \\
\text { Rata-Rata }\end{array}$ & $\begin{array}{l}\text { Deviasi } \\
\text { Standar }\end{array}$ \\
\hline Pengungkapan ERM & 46 & 0,474 & 1,000 & 0,824 & 0,140 \\
\hline Umur Perusahaan & 46 & 14,055 & 67,088 & 40,403 & 14,143 \\
\hline Ukuran Perusahaan & 46 & 26,292 & 31,190 & 28,653 & 1,512 \\
\hline Nilai Perusahaan & 46 & 0,273 & 1,359 & 0,914 & 0,194 \\
\hline
\end{tabular}

Sumber: Data Penelitian, 2020

Pengungkapan Enterprise Risk Management (ERM) diproksikan dengan jumlah indikator yang diungkapkan dengan yang seharusnya diungkapkan yaitu 38 indikator proses manajemen risiko ISO 31000: 2018 Risk Management-Guidelines diperoleh nilai rata-rata sebesar 0,824. Nilai ini menunjukkan bahwa dari 46 sampel penelitian, nilai rata-rata yang diprediksi oleh pasar dalam pengungkapan ERM yakni sebesar 0,824. Serta diperoleh juga nilai maksimum sebesar 1,000 dan nilai minimum sebesar 0,474. Nilai deviasi standar sebesar 0,140 hal ini menunjukkan bahwa terjadi perbedaan nilai pengungkapan ERM yang diteliti terhadap nilai rata-ratanya sebesar yakni 0,140.

Umur perusahaan diproksikan dengan tahun perusahaan berdiri sampai pada periode penelitian diperoleh nilai rata-rata sebesar 40,403. Nilai ini menunjukkan bahwa dari 46 sampel penelitian, nilai rata-rata yang diprediksi oleh pasar dalam umur perusahaan yakni sebesar 40,403. Serta diperoleh juga nilai maksimum sebesar 67,088 dan nilai minimum sebesar 14,149. Nilai deviasi standar sebesar 14,149 hal ini menunjukkan bahwa terjadi perbedaan nilai umur perusahaan yang diteliti terhadap nilai rata-ratanya sebesar yakni 14,149.

Ukuran perusahaan diproksikan dengan logaritma natural (Ln) total aset diperoleh nilai rata-rata sebesar 28,653. Nilai ini menunjukkan bahwa dari 46 sampel penelitian, nilai rata-rata yang diprediksi oleh pasar dalam ukuran perusahaan yakni sebesar 28,653 . Serta diperoleh juga nilai maksimum sebesar 31,190 dan nilai minimum sebesar 26,292. Nilai deviasi standar sebesar 1,512 hal ini menunjukkan bahwa terjadi perbedaan nilai ukuran perusahaan yang diteliti terhadap nilai rata-ratanya sebesar yakni 1,519. 
Nilai perusahaan diproksikan dengan Tobins's $Q$ yang kemudian diperoleh nilai rata-rata sebesar 0,914 . Hal ini menunjukkan bahwa dari 46 sampel penelitian, nilai rata-rata atas kombinasi variabel yang penting dalam nilai perusahaan berupa pengungkapan Enterprise Risk Management (ERM), umur dan ukuran perusahaan yakni sebesar 0,914 . Serta diperoleh juga nilai maksimum sebesar 1,359 dan nilai minimum sebesar 0,273. Nilai deviasi standar sebesar 0,194 hal ini menunjukkan bahwa terjadi perbedaan nilai dari nilai perusahaan yang diteliti terhadap nilai rata-ratanya sebesar yakni 0,194.

Uji statistik yang digunakan untuk menguji normalitas data adalah dengan menggunakan uji Kolmogorov-Smirnov (K-S) test. Adapun pengujian normalitas disajikan pada Tabel 3.

Tabel 3. Uji Normalitas

\begin{tabular}{lc}
\hline & Unstandardized Residual \\
\hline $\mathrm{N}$ & 46 \\
Asymp.Sig.(2-tailed) & 0,200 \\
\hline
\end{tabular}

Sumber: Data Penelitian, 2020

Hasil uji normalitas pada Tabel 3, menunjukkan bahwa nilai dari Asymp. Sig. sebesar 0,200 yang bernilai lebih besar dari $\alpha=0,05(0,200>0,05)$. Maka dapat disimpukan bahwa data yang digunakan telah terdistribusi secara normal. Uji autokorelasi dilakukan dengan menggunakan Uji Durbin-Watson. Hasil pengujian menunjukkan bahwa nilai dari Durbin-Watson (d) sebesar 2,004. Nilai tersebut selanjutnya akan disesuaikan dengan kriteria pengujian, serta membandingkannya dengan menggunakan tabel Durbin-Watson.

Persamaan dengan kriteria $\mathrm{n}=46$ dan $\mathrm{k}=5$ pada tabel Durbin-Watson diperoleh nilai $\mathrm{dL}=1,287$ dan $\mathrm{dU}=1,776$ serta hasil pengujian diperoleh nilai $\mathrm{d}=$ 2,004. Jika disesuikan dengan kriteria pengujian yang diharapkan yakni $\mathrm{dU}<\mathrm{d}<$ 4 - dU, maka diperoleh hasil 1,776 $<2,004<2,224$ dan nilainya telah sesuai dengan kriteria pengujian. Maka dapat disimpulkan bahwa data penelitian ini tidak terdapat autokorelasi. Uji heteroskedastisitas dilakukan dengan meregresi nilai absolute residual dari model yang diestimasi terhadap variabel bebas, dan diharapkan tidak ada satupun variabel bebas yang berpengaruh signifikan terhadap nilai absolute residual. Adapun pengujian heteroskedastisitas disajikan pada Tabel 4.

Tabel 4. Uji Heteroskedastisitas

\begin{tabular}{lc}
\hline \multicolumn{1}{c}{ Variabel } & $\begin{array}{c}\text { Signifikansipada } \\
\text { absolute residual }\end{array}$ \\
\hline Pengungkapan ERM & 0,371 \\
Umur Perusahaan & 0,592 \\
Ukuran Perusahaan & 0,676 \\
Pengungkapan ERM*Umur Perusahaan & 0,384 \\
Pengungkapan ERM*UkuranPerusahaan & 0,510 \\
\hline
\end{tabular}

Sumber: Data Penelitian, 2020

Hasil uji heteroskedastisitas pada Tabel 4, menunjukkan bahwa nilai signifikansi pada absolute residual yang diperoleh masing-masing variabel dari telah bernilai lebih besar dari $a=0,05$. Maka dapat disimpukan bahwa data yang digunakan tidak terjadi gejala heteroskedastisitas. Melalui pengujian Moderated Regression Analysis pada Tabel 5. dihasilkan persamaan regresi sebagai berikut.

$$
Y=7,772-6,857 X_{1}-0,045 Z_{1}-0,202 Z_{2}+0,052 X_{1} * Z_{1}+0,196 X_{1} * Z_{2}
$$


Nilai konstanta 7,772 memiliki arti apabila probabilitas pengungkapan Enterprise Risk Management (ERM), umur perusahaan, ukuran perusahaan, interaksi pengungkapan ERM dengan umur perusahaan, interaksi pengungkapan ERM dengan ukuran perusahaan sama dengan nol, maka nilai perusahaan bernilai sebesar 7,772 dari nilai bukunya.

Tabel 5. Uji Moderated Regression Analysis

\begin{tabular}{lccccc}
\hline \multirow{2}{*}{ Model } & \multicolumn{2}{c}{$\begin{array}{c}\text { Unstandardized } \\
\text { Coefficients }\end{array}$} & $\begin{array}{c}\text { Standardized } \\
\text { Coefficients }\end{array}$ & p-value & Keterangan \\
\cline { 2 - 5 } & $\mathrm{B}$ & Std. Error & Beta & & \\
\hline (Constant) & 7,772 & 2,593 & & 0,005 & \\
Pengungkapan ERM & $-6,857$ & 3,242 & $-4,939$ & 0,041 & Signifikan \\
Umur Perusahaan & $-0,045$ & 0,015 & $-3,315$ & 0,004 & Signifikan \\
Ukuran Perusahaan & $-0,202$ & 0,087 & $-1,574$ & 0,026 & Signifikan \\
ERM*Umur & 0,052 & 0,018 & 3,856 & 0,006 & Signifikan \\
ERM*Ukuran & 0,196 & 0,108 & 4,461 & 0,077 & TidakSignifikan \\
\hline Adjusted R Square & & & & & 0,273 \\
Sig.F & & & & & 0,003 \\
\hline
\end{tabular}

Sumber: Data Penelitian, 2020

Hasil pengujian pada Tabel 5, menunjukkan nilai signifikansi uji $\mathrm{t}$ dari variabel pengungkapan Enterprise Risk Management (ERM) sebesar 0,041 nilai tersebut lebih kecil dari $a=0,05(0,041<0,05)$ yang berarti signifikan. Serta diperoleh nilai koefisien regresi sebesar -6,857. Hal ini menunjukkan bahwa probabilitas pengaruh pengungkapan Enterprise Risk Management (ERM) berpengaruh negatif pada nilai perusahaan, sehingga hipotesis pertama dalam penelitian ini ditolak.

Hipotesis pertama adalah pengungkapan Enterprise Risk Management berpengaruh positif pada nilai perusahaan. Berdasarkan hasil pengujian hipotesis, diperoleh bahwa pengungkapan Enterprise Risk Management belum mampu membuktikan pengaruh positif pada nilai perusahaan lembaga pembiayaan dan asuransi tahun 2018-2019. Hal ini artinya semakin banyak pengungkapan Enterprise Risk Management yang dilakukan oleh lembaga pembiayaan dan asuransi tahun 2018-2019 maka semakin kecil nilai perusahaan tersebut. Lembaga pembiayaan dan asuransi yang merupakan jenis perusahaan Lembaga Jasa Keuangan Non-Bank (LJKNB) memiliki kewajiban untuk mengungkapkan Enterprise Risk Management. Karena pengungkapan Enterprise Risk Management merupakan suatu kewajiban maka para investor tidak memperhatikan pengungkapan Enterprise Risk Management sebagai dasar menilai perusahaan. Terbukti pada hasil uji statistik deskriptif rata-rata pengungkapan Enterprise Risk Management pada lembaga pembiayaan dan asuransi tahun 2018-2019 adalah sebesar 0.82 atau $82 \%$, artinya pengungkapan Enterprise Risk Management oleh lembaga pembiayaan dan asuransi tahun 2018-2019 adalah tinggi.

Hasil penelitian ini tidak sejalan dengan teori sinyal, dimana Enterprise Risk Management sebagai informasi non keuangan belum mampu menjadi sinyal good news bagi investor lembaga pembiayaan dan asuransi tahun 2018-2019. Peneliti berasumsi bahwa salah satu atau beberapa indikator Enterprise Risk Management yang diungkapkan oleh perusahaan dapat meresahkan investor dikarenakan investor tidak menyukai informasi tersebut. Ketika investor mendapatkan 
informasi risiko yang tidak terduga diungkapkan oleh perusahaan, maka investor akan ragu berinvestasi karena risiko erat hubungannya dengan kerugianjika tidak dapat dimitigasi dengan baik. Semakin banyak informasi yang diungkapkan oleh perusahaan maka investor akan semakin bingung menilai perusahaan, karena informasi yang dibutuhkan investor adalah informasi secukupnya sehingga yang dibutuhkan investor adalah informasi yang tepat.

Hasil penelitian ini tidak sejalan dengan Bertinetti et al. (2013), Devi et al. 2017, Hoyt \& Liebenberg (2011), Iswajuni et al. (2018), Sari (2020) yang meneliti hubungan antara Enterprise Risk Management dengan nilai perusahaan dan menemukan bahwa penerapan Enterprise Risk Management berdampak positif pada nilai perusahaan. Hasil penelitian ini juga tidak sejalan dengan penelitian yang dilakukan oleh Aditya \& Naomi (2017), Ardianto \& Rivandi (2018), Mariani \& Suryani (2018), Pamungkas \& Maryati (2017) yang menyatakan bahwa enterprise risk management tidak berpengaruh pada nilai perusahaan. Jadi hasil penelitian ini yang menemukan bahwa pengungkapan enterprise risk management berpengaruh negatif signifikan pada nilai perusahaan lembaga pembiayaan dan asuransi tahun 2018-2019 adalah wajar karena nilai perusahaan lembaga pembiayaan dan asuransi tahun 2018-2019 terkena imbas penurunan kepercayaan publik atas kasus penyalahgunaan kewenangan mengelola risiko yang dilakukan oleh PT Asuransi Jiwasraya dan PT Sunprima Nusantara Pembiayaan/SNP Finance.

Berdasarkan Tabel 5. nilai signifikansi uji $t$ dari variabel pengungkapan $\mathrm{ERM}^{*}$ Umur perusahaan yang merupakan pengujian variabel umur perusahaan dalam memoderasi pengaruh pengungkapan ERM pada nilai perusahaan, diperoleh nilai koefisien regresi sebesar 0,052 serta nilai $p$-value sebesar 0,006 nilai tersebut lebih kecil dari $a=0,05(0,006<0,05)$ yang berarti signifikan. Karena merupakan pengujian pengaruh moderasi, hasil tersebut perlu dipadukan dengan nilai signifikansi dari variabel umur perusahaan. Variabel umur perusahaan memperoleh nilai koefisien regresi sebesar $-0,045$ serta nilai $p$-value sebesar 0,004 nilai tersebut lebih kecil dari $a=0,05(0,004<0,05)$ yang berarti signifikan. Oleh karena variabel ERM*Umur bernilai positif signifikan dan variabel umur perusahaan bernilai negatif signifikan, maka variabel umur perusahaan merupakan variabel moderasi yang dapat memperlemah pengaruh negatif pengungkapan Enterprise Risk Management pada nilai perusahaan serta variabel umur perusahaan merupakan jenis moderasi semu/quasi moderator. Hal ini menunjukkan bahwa probabilitas umur perusahaan dapat memoderasi pengaruh pengungkapan Enterprise Risk Management pada nilai perusahaan, sehingga hipotesis kedua dalam penelitian ini diterima.

Hipotesis kedua adalah umur perusahaan memperkuat pengaruh pengungkapan Enterprise Risk Management pada nilai perusahaan. Berdasarkan hasil pengujian hipotesis, diperoleh bahwa umur perusahaan mampu membuktikan dalam memperlemah pengaruh negatif pengungkapan Enterprise Risk Management pada nilai perusahaan lembaga pembiayaan dan asuransi tahun 2018-2019. Hal ini artinya pengungkapan Enterprise Risk Management mampu meningkatkan nilai perusahaan dalam kondisi umur perusahaan dewasa. Hal ini karena lembaga pembiayaan dan asuransi yang telah lama berdiri yang ditunjukan dengan umur perusahaan yang panjang dapat menunjukan eksistensi perusahaan. Lembaga pembiayaan dan asuransi adalah jenis jasa keuangan. 
Faktor yang menunjukkan bahwa jasa keuangan dipercaya publik adalah perusahaan yang telah lama berdiri, sehingga semakin lama berdiri maka akan mendapatkan kepercayaan publik yang artinya perusahaan memiliki kelangsungan hidup yang baik.

Hasil penelitian ini sejalan dengan teori sinyal, yaitu semakin stabil kondisi sebuah perusahaan akan membuat pemimpin perusahaan mengungkapkan Enterprise Risk Management dengan transparan untuk memberikan sinyal positif untuk menarik investor berinvestasi di perusahaan tersebut. Hasil penelitian sejalan dengan hasil penelitian pengungkapan informasi perusahaan seperti corporate social responsibillity (CSR) yaitu D'Amato \& Falivena (2020) yang menemukan bahwa umur perusahaan mempekuat pengaruh positif pengungkapan CSR pada nilai perusahaan.

Berdasarkan Tabel 5, nilai signifikansi uji $t$ dari variabel pengungkapan ERM*ukuran perusahaan yang merupakan pengujian variabel ukuran perusahaan dalam memoderasi pengaruh pengungkapan ERM pada nilai perusahaan, diperoleh nilai koefisien regresi sebesar 0,196 serta nilai $p$-value sebesar 0,077 nilai tersebut lebih besar dari a = 0,05 $(0,077>0,05)$ yang berarti tidak signifikan, karena merupakan pengujian pengaruh moderasi, hasil tersebut perlu dipadukan dengan nilai signifikansi dari variabel ukuran perusahaan. Variabel ukuran perusahaan memperoleh nilai koefisien regresi sebesar $-0,202$ serta nilai $p$-value sebesar 0,026 nilai tersebut lebih kecil dari $\alpha=0,05(0,026<0,05)$ yang berarti signifikan. Oleh karena variabel ERM*Ukuran bernilai positif tidak signifikan dan variabel ukuran perusahaan bernilai negatif signifikan, maka variabel ukuran perusahaan merupakan jenis prediktor moderasi. Hal ini menunjukkan bahwa probabilitas ikuran perusahaan tidak dapat memoderasi pengaruh pengungkapan Enterprise Risk Management pada nilai perusahaan, sehingga hipotesis ketiga dalam penelitian Hipotesis ketiga adalah ukuran perusahaan memperkuat pengaruh pengungkapan Enterprise Risk Management pada nilai perusahaan. Berdasarkan hasil pengujian hipotesis, diperoleh bahwa ukuran perusahaan belum mampu membuktikan pengaruh moderasi dalam pengungkapan Enterprise Risk Management pada nilai perusahaan lembaga pembiayaan dan asuransi tahun 20182019. Hal ini artinya pengungkapan Enterprise Risk Management belum mampu memengaruhi nilai perusahaan dalam kondisi besar ataupun kecil aset yang dimiliki oleh suatu perusahaan. Hal ini karena pada Lembaga Jasa Keuangan NonBank (LJKNB) tidak terdapat klasifikasi jumlah aset yang dimiliki perusahaan terhadap jumlah pengungkapan risiko yang harus diungkapkan. Pada Lembaga Jasa Keuangan Non-Bank (LJKNB) semua perusahaan diwajibkan menerapkan jenis risiko yang telah di atur pada peraturan OJK No.44/POJK.05/2020 tentang penerapan manajemen risiko Lembaga Jasa Keuangan Non-Bank (LJKNB).

Hasil penelitian ini tidak sejalan dengan agency theory, yaitu semakin besar ukuran suatu perusahaan maka transparansi pengelolaan risiko semakin luas, ini dikarenakan ukuran perusahaan yang besar memungkinkan banyak risiko yang dihadapi perusahaan (Rujiin \& Sukirman, 2020). Ukuran perusahaan yang besar berarti semakin banyak investor menanamkan modal di perusahaan tersebut. Hal ini menyebabkan perusahaan memiliki kewajiban mengungkapkan Enterprise Risk Management (ERM) kepada pihak prinsipal (pemegang saham) sebagai bentuk tanggungjawab kepada investor bahwa perusahaan mampu sebagai wakil dalam 
mengelola modal dan risiko yang dihadapi perusahaan. Hal ini berarti ukuran aset perusahaan tidak ada pengaruh pada pengungkapan Enterprise Risk Management pada nilai perusahaan. Hasil penelitian ini bertentangan dengan hasil penelitian pengungkapan informasi perusahaan seperti D'Amato \& Falivena (2019) yang menemukan bahwa umur perusahaan memperkuat pengaruh positif pengungkapan corporate social responsibillity (CSR) pada nilai perusahaan. Kemudian hasil penelitian Narayana \& Wirakusuma (2021) yang menemukan bahwa umur perusahaan memperkuat pengaruh positif pengungkapan CSR pada nilai perusahaan. Perbedaan hasil penelitian ini mungkin terjadi karena perbedaan jenis perusahaan yang diteliti ini ditolak.

\section{SIMPULAN}

Berdasarkan hasil analisis dapat disimpulkan bahwa pengungkapan Enterprise Risk Management belum berhasil membuktikan bahwa memiliki pengaruh positif pada nilai perusahaan lembaga pembiayaan dan asuransi tahun 2018-2019. Semakin besar pengungkapan Enterprise Risk Management oleh perusahaan lembaga pembiayaan dan asuransi tahun 2018-2019, maka akan memberikan sinyal negatif kepada pada para investor sehingga dapat menurunkan nilai perusahaan. Umur perusahaan berhasil membuktikan bahwa memperlemah pengaruh negatif pengungkapan Enterprise Risk Management pada nilai perusahaan lembaga pembiayaan dan asuransi tahun 2018-2019. Pengungkapan Enterprise Risk Management akan meningkatkan nilai perusahaan dalam kondisi umur perusahaan yang semakin dewasa. Ukuran perusahaan tidak mampu membuktikan bahwa memperkuat pengaruh pengungkapan Enterprise Risk Management pada nilai perusahaan lembaga pembiayaan dan asuransi tahun 20182019. Besar atau kecilnya ukuran perusahaan belum terbukti memperkuat pengaruh pengungkapan Enterprise Risk Management pada nilai perusahaan.

Peneliti menyadari bahwa penelitian ini hanya terbatas pada pengungkapan Enterprise Risk Management yang mengacu pada proses manajemen risiko ISO 31000: 2018 Risk Management-Guidelines. Padahal dalam ISO 31000: 2018 Risk Management-Guidelines terdapat tiga komponen yang harus saling berhubungan satu dengan yang lainnya pada suatu perusahaan, yaitu prinsip, kerangka kerja dan proses manajemen risiko. Untuk penelitian selanjutnya diharapkan dapat mengeksplor ISO 31000: 2018 Risk Management-Guidelines untuk membangun indikator, sehingga dapat merumuskan indikator yang lebih baik. Sehingga hasil penelitian pada lembaga pembiayaan dan asuransi akan memberikan wawasan berbeda untuk penelitian terkait Enterprise Risk Management. Kemudian penelitian selanjutnya diharapkan mampu menemukan indikator Enterprise Risk Management yang sering diungkapkan perusahaan namun tidak disukai investor sehingga dapat memberikan penjelasan yang tepat jika hasil penelitian selanjutnya adalah negatif signifikan.

\section{REFERENSI}

Aditya, O., \& Naomi, P. (2017). Penerapan Manajemen Risiko Perusahaan dan Nilai Perusahaan di Sektor Konstruksi dan Properti. Esensi: Jurnal Bisnis Dan Manajemen, 7(2), 167-180. https:// doi.org/10.15408/ess.v7i2.4981

Akerlof, G. A. (1970). The marketfor "lemons": Quality uncertainty and themarket 
mechanism. Quarterly Journal of Economics, 84(3), 488-500. https:/ / doi.org/10.2307/1879431

Ardianto, D., \& Rivandi, M. (2018). Pengaruh Enterprise risk Management Disclosure dan Struktur Pengelolaan terhadap Nilai Perusahaan. Profita: Komunikasi Ilmiah Akuntansi Dan Perpajakan, 11(2), 284-305.

Baxter, R., Bedard, J. C., Hoitash, R., \& Yezegel, A. (2013). Enterprise risk management program quality: Determinants, value relevance, and the financial crisis. Contemporary Accounting Research, 30(4), 1264-1295. https:/ / doi.org/10.1111/j.1911-3846.2012.01194.x

Bertinetti, G. S., Cavezzali, E., \& Gardenal, G. (2013). The Effect of the Enterprise Risk Management Implementation on the Firm Value of European Companies. SSRN Electronic Journal, 10. https:/ / doi.org/10.2139/ssrn.2326195

Bogodistov, Y., \& Wohlgemuth, V. (2017). Enterprise risk management: a capability-based perspective. Journal of Risk Finance, 18(3), 234-251. https:/ / doi.org/10.1108/JRF-10-2016-0131

D'Amato, A., \& Falivena, C. (2020). Corporate social responsibility and firm value: Do firm size and age matter? Empirical evidence from European listed companies. Corporate Social Responsibility and Environmental Management, 27(2), 909-924. https:// doi.org/10.1002/csr.1855

Del Brio, E., De Miguel, A., \& Pindado, J. (2003). Investment and firm value: An analysis using panel data. Applied Financial Economics, 13(12), 913-923. https:/ / doi.org/10.1080/0960310032000082079

Devi, S., Budiasih, I. G. N., \& Badera, I. D. N. (2017). Pengaruh Pengungkapan Enterprise Risk Management Dan Pengungkapan Intellectual Capital Terhadap Nilai Perusahaan. Jurnal Akuntansi Dan Keuangan Indonesia, 17(1), 20-45. https:/ / doi.org/10.21002/jaki.2017.02

Dushnitsky, G., \& Lenox, M. J. (2006). When does corporate venture capital investment create firm value? Journal of Business Venturing, 21(6), 753-772. https:/ / doi.org/10.1016/j.jbusvent.2005.04.012

Ehie, I. C., \& Olibe, K. (2010). The effect of R\&D investment on firm value: An examination of US manufacturing and service industries. International Joumal of Production Economics, 128(1), 127-135. https:/ / doi.org/10.1016/j.ijpe.2010.06.005

Harmono. (2009). Manajemen Keuangan Berbasis Balance Scorecard. Pendekatan Teori, Kasus dan Riset Bisnis. Jakarta: Bumi Aksara.

Hoyt, R. E., \& Liebenberg, A. P. (2011). The Value of Enterprise Risk Management. Journal of Risk and Insurance, 78(4), 795-822. https:/ / doi.org/10.1111/j.15396975.2011.01413.x

Iswajuni, I., Soetedjo, S., \& Manasikana, A. (2018). Pengaruh Enterprise Risk Management (Erm) Terhadap Nilai Perusahaan Pada Perusahaan Manufaktur Yang Terdaftar Di Bursa Efek. Journal Of Applied Managerial Accounting, 2(2), 147-153. https://doi.org/10.30871/jama.v2i2.942

Jensen, M., \& Meckling, W. (1976). Theory of the Firm: Managerial Behavior, Agency Costs and Capital Structure. Journal of Financial Economics, 305-306.

Khanna, N., \& Sonti, R. (2004). Value creating stock manipulation: Feedback effect of stock prices on firm value. Journal of Financial Markets, 7(3), 237-270. 
https:/ / doi.org/10.1016/j.finmar.2003.11.004

Mariani, D., \& Suryani. (2018). Pengaruh ERM Disclosure, IC Disclosure, Dan CSR Disclosure Terhadap Nilai Perusahaan Dengan Profitabilitas Sebagai Variabel Pemoderasi. Jurnal Akuntansi Dan Keuangan, 7(2), 119-138.

Narayana, I. P. L., \& Wirakusuma, M. G. (2021). Pengungkapan CSR pada Nilai Perusahaan dengan Profitabilitas dan Ukuran Perusahaan sebagai Variabel Moderasi. E-Jurnal Akuntansi, 31(4), 862-879. https:/ / doi.org/10.24843/eja.2021.v31.i04.p06

Pamungkas, A. S., \& Maryati, S. (2017). Pengaruh Enterprise Risk Management Disclosure, Intellectual Capital Disclosure dan Debt to Asset Ratio Terhadap Nilai Perusahaan. Semnas IIB Darmajaya Lembaga Penelitian, Pengembangan Pembelajaran \& Pengabdian Kepada Masyarakat.

Ross, S. A., Westerfield, R. W., \& Jaffe., J. (2013). Corporate Finance, 10th Edition. McGraw-Hill.

Rujiin, C., \& Sukirman, S. (2020). The Effect of Firm Size, Leverage, Profitability, Ownership Structure, and Firm Age on Enterprise Risk Management Disclosures. Accounting Analysis Journal, 9(1), 81-82. https:/ / doi.org/10.15294/aaj.v9i2.33025

Rura, Y. (2010). Pengungkapan Pro Forma, Mendukung atau Menyesatkan Investor? Jurnal Akuntansi Multiparadigma, 1(3), 375-392. https:/ / doi.org/10.18202/jamal.2010.12.7099

Sari, I. O. (2020). Pengungkapan Enterprise Risk Management sebagai Penentu Nilai Perusahaan dengan Profitabilitas sebagai Moderasi. Skripsi. Universitas Muhamadyah Malang.

Suryani. (2017). Pengaruh Karakteristik Informasi Sistem Akuntansi Manajemen Terhadap Kinerja Manajerial Dengan Ketidakpastian Lingkungan Dan Desentralisasi Sebagai Variabel Moderating. Jurnal Akuntansi Dan Keuangan FEB Universitas Budi Luhur, 6(2), 201-220. https://doi.org/.1037//00332909.I26.1.78

Susilo, L. J., \& Riwu, K. V. (2018). Manajemen Risiko Berbasis ISO 31000: 2018 Panduan Untuk Risk Leader dan Risk Practitioner. Jakarta: PT Grasindo.

Utomo, N. A., \& Christy, N. N. A. (2017). Pengaruh Stuktur Modal, Profabilitas, Ukuran Perusahaan terhadap Nilai Perusahaan pada Perusahaan LQ45 di Bursa Efek Indonesia. Bingkai Manajemen, 1(1), 399-415. 